\title{
Chemical Composition and Antioxidants of Lepidium Sativum and L. aucheri
}

\author{
Ola Adel Al-Saad \\ Biology Department, \\ Science Collegel \\ Basrah University/ \\ Iraq. \\ saharmalik2010@gmail.com \\ Sahar A. A. Malik Al-Saadi \\ Biology Department, \\ Science College \\ Basrah University, \\ Iraq. \\ https://doi.org/10.32792/utq/utjsci/v8/1/7
}

\begin{abstract}
Antioxidant activity of total glucosides contents of the extract of Lepidium sativum and Lepidium aucheri leaves was determined using free radical scavenging activity 2,2Diphenyl-1-Picrylhydrazyle (DPPH) by adding different concentrations of glycoside to DPPH. The inhibitory activity determined by using five different concentrations of glycolysis of $L$. sativum and $L$. aucheri leaves extracts. The results indicated that $1000 \mathrm{mg} / \mathrm{ml}$ concentration showed radical scavenging activity as strong as than low concentrations. Out of the two species $L$. aucheri had the greatest abundance of antioxidant compared with $L$. sativum. The inhibition percentage of $L$. sativum as found to be 78.211 in $1000 \mu \mathrm{g} / \mathrm{mL}$, was comparatively lower than of standard ascorbic acid and $L$. aucheri extract 91.972 and $97.018 \mu \mathrm{g} / \mathrm{mL}$, respectively. $L$. aucheri extract has strong activity that reach almost as high as ascorbic acid.
\end{abstract}

Total antioxidant capacity of the test samples was calculated using the standard line as ascorbic acid equivalents (AAE) per gram of the leaves extract, of ascorbic acid ( $y=$ $\left.0.0629 x+48.356, R^{2}=0.4085\right)$. The results of $L$. sativum and $L$. aucheri was $\left(\mathrm{y}=0.0436 \mathrm{x}+43.48, \mathrm{R}^{2}=0.3493\right)$ and $(0.0648 x+$ 48.761, $\left.R^{2}=0.3483\right)$ respectively. The two species with various concentration showed the strongest antioxidant activity with its significantly smaller $\mathrm{IC}_{50}$ values,the best exhibited a quite recorded in $L$. aucheri $\left(\mathrm{IC}_{50}=19.12 \mu \mathrm{g} / \mathrm{mL}\right.$, followed by $L$. astivum $149.541 \mu \mathrm{g} / \mathrm{mL}$. compared with ascorbic acid 26.136 $\mu \mathrm{g} / \mathrm{mL}$.

The GC analysis indicated that $L$. sativum had high number of glycoside compounds 36 components compared with $L$. aucheri 19 components. The major components of $L$. sativum were found to be: Benzyl nitrile $(22.24 \%)$, N,NDimethylaminoethanol (17.53\%), 2-Hydroxy-1-(1'-pyrrolidiyl)1-buten-3-one (11.08\%), D-Proline (7.33 \%), Butyrolactone (4.97\%) and 1-(1'-pyrrolidinyl)-2-propanone (4.14), GC -MS analysis of $L$. aucheri represented DL-Proline, 5-oxo-, methyl ester (42.26\%); 2-Furancarboxaldehyde, 5-methyl- (12.64\%); 4H-Pyran-4-one, 2,3-dihydro-3,5-dihydroxy-6-methyl(9.87\%); Hexadecanoic acid, 2-hydroxy-1(hydroxymethyl)ethyl ester (2.33\%); 2-Methoxy-4-vinylphenol (2.02\%).

Keywords- Antioxidant activity, GC-MS, $L$. sativum, L. aucheri, Chemical compounds.

\section{INTRODUCTION}

The Cruciferae (Brassicaceae) is one of the largest families of Angiosperms, also known as the mustard family. The family mustard is widespread in the world, especially in the Mediterranean region, it was grown in the cold and temperate regions of the northern hemisphere, which includes about (338 -500) genera and (3000-2000) (Al-Mayah, 2001; Al-Shehbaz; 1984, Al-Musawi, 1987; Ait-yahia et al., 2018). In Iraq, they have almost 80 genera and more than 177 species spread over 10 Tribes (Townsend, and Guest, 1980).

L. sativum $\mathrm{L}$. and $L$. aucheri are a small, annual herb, known as 'Rhashad' in Iraq but in some regions called Garden cress, pepperwort, pepper grass, While L. aucheri called 'Rhashad barri'. L. sativum are widely used in Arabic countries for their medicinal properties. L. sativum about $15-50 \mathrm{~cm}$ in height, while $L$. aucheri up to $30 \mathrm{~cm}$ high, L. sativum is glabrous, contains branches on the upper parts, the flowers are clustered in branched racemes, white to pinkish flowers. L. aucheri recognized the branches and whole plant with purple tinge and few leaves, fruit small siliculas (Facciola, 1990; Abdel karim et al., 2017; Hussein et al., 2017; Singh and Singh, 2018).

L. sativum and L. aucheri are have several and traditionally properties. Literature search reported that analgesic, aperient, anti-anemic activity, alternative, exhibit an oral contraceptive, antihypertensive effect, Tachyphylactic, hypoglycemia antidiarrheal, antispasmodic, laxative, antirheumatic, anticoagulant, antiinflammatory, anticancer activity; asthma, cough, diarrhea, dysentery, skin disease, aphrodisiac and carminative properties (Ahsan et.al.1989; Patel et al., 2009; Maghrani et al.,2005; Mullen et al., 2007; Ravi et.al.,2011; Kbyeh , 2015; Abdel

Website: https://utjsci.utq.edu.iq/index.php/main, Email: utjsci@utq.edu.iq 
karim et al., 2017). Hussein et al (2017) reported that L. sativum is useful in swelling, stiffness, anti-diarrheal, cardiotonic, hypotensive, antimicrobial, bronchodilator, and hypoglycemic applications. L. sativum young leaves are eaten raw or cooked, while its seeds are used in peppery flavor. The seeds are used in treatment of chronic liver enlargement and spleen diseases. (Usher,1974; Merzouki et al., 2000; Mullen et al., 2007; Datta et al., 2011; Fan et al., 2014; Xiao et al., 2014; Hussein et al., 2017; Singh and Singh, 2018).

phytochemical studies of L. sativum showed presence of alkaloids, flavonoids, fatty acids, coumarins, flavonols, glycosylation (mono, di and triglycoside). sulphur glycosides, glucosinolate) triterpenes, sterols, phosphorus, thiamine, and niacin, sinapoyl malate, sinapic acid, sinapine and various imidazole alkaloids (Abdel karim et al.,2017; Hussein et al., 2017; Singh and Singh 2018). As well as contains amount of uric acid, iron, carotene, calcium, folic acid beside vitamins A and C. As well as, it contains protein; leucine; glutamic acid and methionin. glucosinolates are the major secondary compounds. Malar et al., (2018) reported that the seeds of $L$. sativum contains two glucosinolates, glucotropaeolin and gluconasturin (Singh and Singh, 2018). Flavonoids (flavones, flavanones, flavonols, isoflavones, flavanols, chalcones and anthocyanins) are present in this plant and they are commonly found conjugated to sugars in the form of O-glycosides or C-glycosides forms isothiocyanates, which is formed with glucosinolates (Kassie et al., 2002; Al-Snafi, 2019).

In recent years GC-MS analysis have been proved a valuable method for the identified of components (Hussein et al., 2017). The GC-MS spectrum revealed 19 compounds in methanolic extract of $L$. sativum leaves such as Glycerin, Furfural, Allyl isothiocyanate. While methanolic seeds extract showed the presence of 46 compounds included 4H-pyran-4-one, 2furancarboxaldehyde thiocyanic acid, 2-methoxy4vinylphenol, d-mannose (Al-Snafi, 2018). 15 compounds identified by GC-MS analysis of total alkaloidal extract from $L$. sativum seeds reported by (Singh and Singh, 2018). 83 compounds were identified of methanol extract of seeds (Benzyl nitrile, Squalene, Hexanedioic acid, dimethyl ester and Azulene (Abu-Rumman, 2018). Lee and Chang (2019) recorded 25 chemical compounds in methanol extract of L. meyenii.

Medicinal plants are important sources of antioxidant. Brassicaceae crops are among those plants that have the highest antioxidant activity (Wang and Zheng, 2001; Soengas et al. 2012). reported that phenolic content gives a strongest and the highest antioxidant activity. Ethanolic extract of $L$. sativum leaf, shoot and stem were studied against DPPH, high scavenging activity was observed in the shoot (12.19 $\pm 02 \%)$. (Malar et al., 2018). Flavonols have antioxidant activity and important in inhibition of cancer cell proliferation (Ait-Yahia et al., 2015). Significant antioxidant activity noticed of methanol extract of $L$. sativum subsp spinescens and Lepidium meyenii Walp (Selek et al., 2018; Lee and Chang, 2019).

Antioxidant activities by (DPPH) freeradical-scavenging assays for EC50 were determined as 330.99 (Dadas) and 346.65 (Izmir) (Sat et al., 2013). The IC50 for scavenging DPPH was $0.61 \mathrm{mg} / \mathrm{ml}$ of Lepidium meyenii (Sandovala et al., 2002). While seeds extract has good DPPH radical scavenging activity and IC (Eddouks et al., 2005). The Oz (2011) determined that antioxidant capacity of a L.sativum as EC50 was 233.475 $\mathrm{mg} / \mathrm{ml}$. The maximum increase in antioxidant activity in petroleum ether extract was observed $3.125 \mathrm{mg} / \mathrm{ml}$ to $6.25 \mathrm{mg} / \mathrm{ml}$ (Bhasin et al., 2011). The antioxidant activity of the methanol extract of L. sativum found that the IC50 values are $62 \mu \mathrm{g} / \mathrm{ml}$ (Ahamad et al., 2015) and IC50 of 925.22 \pm 0.02 ppm (Chatoui et al., 2016). Ethanol extract showed concentration-dependent antioxidant activity (0.146 to $18.75 \mathrm{mg} / \mathrm{ml}$ ) (Al-Snafi, 2019).

The aim of this study was a quantity - quality analysis of the glycoside composition by using GC-MS analysis and antioxidant properties of glycoside extracts of L. sativum and L. aucheri leaves.

\section{II. . MATERIALS AND METHODS}

\section{1- Plant collection}

Lepidium sativum $\mathrm{L}$. and $L$. aucheri leaves were collected from the Basrah city - Iraq in March 2019. The leaves were identified according to the flora of Iraq. Leaves air dried until used.

\section{2- Determination of total glucosides contents}

Glycosides extraction: Method of (Harborne,1984) with some modification was 
followed: $25 \mathrm{gm}$ of plant powder added to $250 \mathrm{ml}$ of ethyl alcohol (70\%), leave mixture for 24 hours in the magnetic stirrer and filtrated for getting ethanol extract. extract was concentrated by rotary evaporator, $50 \mathrm{ml}$ of $\mathrm{n}$-butanol were added to the mixture by separation funnel with shaking and pulled the water layer. The process was repeated three times and dried water drawn layer at a temperature of $30 \mathrm{C}^{\circ}$ until full drying and then put the extracts in tubes with lid and kept freeze until use.

\section{3- Determination of antioxidant activity by DPPH assay:}

The antioxidant activity of $L$. sativum and $L$. aucheri leaves glycosides was determined by DPPH assay using (Hatano et al., 1988) with some modifications. The $L$. sativum and $L$. aucheri glycoside extract was prepared in various concentrations $(0,10,25,100,500) \mu \mathrm{g} / \mathrm{ml}$ diluted with methanol. $0.004 \mathrm{mg}$ from DPPH was dissolved in $100 \mathrm{ml}$ of methanol. The absorbance at $517 \mathrm{~nm}$ was determined against control after an incubation for $30 \mathrm{~min}$ at room temperature by using a spectrophotometer. DPPH $(50 \mu \mathrm{g} / \mathrm{ml})$ was used as the control, ascorbic acid as the standard in triplicate for the standard. The antiradical activity was revealed as $\mathrm{IC}_{50}$ of DPPH scavenging activity by observing the 50\% inhibitory concentration for extract using the calibration curve.

Percentage of antioxidant activity of free radical DPPH was calculated as follows:

Antioxidant activity (Inhibition) \% = $\left[\left(\mathrm{A}_{\text {control }}-\mathrm{A}_{\text {sample }}\right) / \mathrm{A}_{\text {control }}\right] \times 100$ Where: $\mathrm{A}_{\text {control }}$ is the absorbance of the control reaction and $\mathrm{A}_{\text {sample }}$ is the absorbance in the presence of extract.

\section{4- GC-MS analysis of glycosides}

GC-MS analysis was carried out by using a Shimadzu GC-QP 2010 ultra-gas chromatograph. The GC oven temperature was programmed from $40^{\circ} \mathrm{C}$ to $280^{\circ} \mathrm{C}$ at hold of $10 \mathrm{C} / \mathrm{min}$. Helium was used as a carrier gas. The pressure was 7.0699 psi. The column flow was $1 \mathrm{~mL} / \mathrm{min}$, and purge flow 3 $\mathrm{ml} / \mathrm{min}$ the injector temperature was $290^{\circ} \mathrm{C}$ with split injection mode. The MS scan conditions incorporate the following: source temperature, $200^{\circ} \mathrm{C}$; interface temperature (MSD transfer line), $290^{\circ} \mathrm{C}$; solvent cut time $4 \mathrm{~min}$, scan speed, 1562 (N2); range $35 \mathrm{~m} / \mathrm{z}$ to, $650 \mathrm{~m} / \mathrm{z}$. Chemical compound of the L. sativum were identified by comparing the spectra with known compounds stored in the NIST library (2005).

\section{RESULTS AND DISCUSSION}

\section{1- Antioxidant assays of $L$. sativum and $L$. aucheri using DPPH radical- scavenging:}

Antioxidant activity of total glucosides contents of the extract was determined using free radical scavenging activity (DPPH) by adding different concentrations of glycoside to DPPH. The inhibitory activity determined by using five different concentrations of glycolysis of $L$. sativum and $L$. aucheri leaves extract are represented in (Figure 1).

The results indicated that $1000 \mathrm{mg} / \mathrm{ml}$ concentration showed radical scavenging activity as strong as than low concentrations (Figure 1). Out of the two species $L$. aucheri had the greatest abundance of antioxidant compared with $L$. sativum. The inhibition percentage of $L$. sativum as found to be $78.211 \%$ in $1000 \mu \mathrm{g} / \mathrm{mL}$, was comparatively lower than of standard ascorbic acid and L. aucheri extract $91.972 \%$ and $97.018 \%$ respectively (Figure 1), L. aucheri extract have strong activity that reach almost as high as ascorbic acid.

Total antioxidant capacity of $L$. sativum leaves glycosides were evaluated as ascorbic acid equivalents (AAE) per gram of the leaf's glycosides extract. Total antioxidant capacity of the test samples was calculated using the standard line of ascorbic acid $\left(\mathrm{y}=0.0629 \mathrm{x}+48.356, \mathrm{R}^{2}=\right.$ $0.4085)$. The glycoside compounds content of the test solutions was calculated using the calibration curve of the standard (Figure 1), The results of $L$. aucheri and L. sativum was $(\mathrm{y}=0.0648 \mathrm{x}+$ $\left.48.761, \mathrm{R}^{2}=0.3483\right)$ and $(\mathrm{y}=0.0436 \mathrm{x}+43.48$, $\mathrm{R}^{2}=0.3493$ ) respectively (Figure 2 and 3 ).

Our results reported that the DPPH radical scavenging activity of the extract from Lepidium species increased with increasing concentration (Sandoval et al. 2002). This may be due to find some chemical compounds have antioxidant activity, which agreed with (Karimi et al.,2011; Vuong et al., 2013).

\section{2- IC 50 assay:}

The antioxidant property of various concentration of $L$. astivum and $L$. aucheri was presented by their $\mathrm{IC}_{50}$ values, all data was 
compared with the $\mathrm{IC}_{50}$ value of standard ascorbic acid, and the results presented in (Figure 4).

The greatest DPPH radical scavenging potency of with a minimum $\mathrm{IC}_{50}$ value was recorded for $L$. aucheri $(19.12 \mu \mathrm{g} / \mathrm{mL})$, followed by ascorbic acid $(26.136 \mu \mathrm{g} / \mathrm{mL})$ and then $L$. sativum $(149.541 \mu \mathrm{g} / \mathrm{mL})$. The $\mathrm{IC}_{50}$ of $L$. sativum obtained in our study was higher compared with some studies conducted to assess the antioxidant activity of the methanol extract of $L$. sativum found that the $\mathrm{IC}_{50}$ values are $62 \mu \mathrm{g} / \mathrm{ml}$ (Ahmad et $a l ., 2015)$, and Aydemir and Sedabecerik (2011) was $\mathrm{IC}_{50}$ value $318.91 \mathrm{ppm}$ for the Turkish $L$. sativum. The scavenging activity might be due to the different in chemical compounds (Czapecka et al., 2005).Chatoui et al. (2016) recorded 925.22 $0.02 \mathrm{ppm}$ from ethanol extract, while Al-Safi (2019) remember it was $0.146-18.75 \mathrm{mg} / \mathrm{ml}$.

The concentration $1000 \mu \mathrm{g} / \mathrm{ml}$ showed the highest capacity to neutralize this radical. The lower the $\mathrm{IC}_{50}$ the higher the antioxidant property of a plant. The $\mathrm{IC}_{50}$ values of the different concentrations of leave extracts of $L$. sativum and L. aucheri. are presented in the (Figure 4). The L.aucheri glycoside compounds exhibited highest antioxidant activity with an $\mathrm{IC}_{50}$ value of 19.12 $\mu \mathrm{g} / \mathrm{mL}$ compared to other fractions. While the value is $26.136 \mu \mathrm{g} / \mathrm{mL}$ for the standard ascorbic acid (Figure 4).

This free radical scavenging activity might be due to the presence of glycoside compounds in the extracts (Ahamad et al., 2015). The phytochemical compound of Lepidium species can donate hydrogen ions to synthetic free radical compound (DPPH), These may be given rise to the major bioactive compounds. These results supported the observation of some researchers reported that the secondary metabolites provide many species of Lepidium have antimicrobial, anticancer, anti-inflammatory activities, and antioxidant effects (Chatoui et al., 2016; AlHarbi, 2018; Alqahtani et al., 2019). Some species of Lepidium caused an increase in the antioxidant levels in the blood and organs (RodriguezHuaman et al., 2017). Studies have showed that extracts from $L$. sativum have antibacterial, antioxidant and antiviral effects. these extracts scavenge the reactive oxygen species and radicals and thus protect the cell from oxidative stress (Ait-yahia et al., 2018).

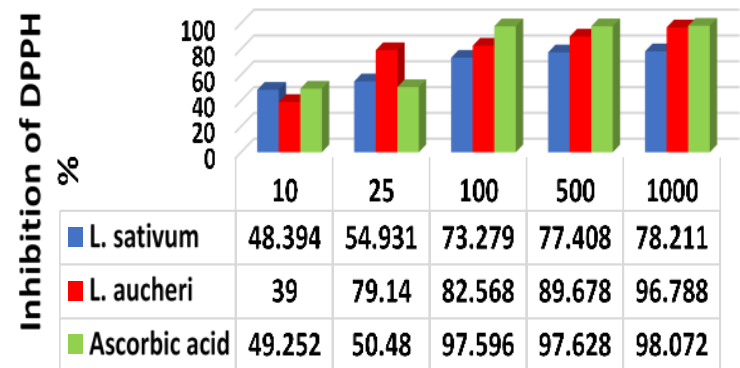

Figure (1) The percentage inhibition of glycosides extracts from $L$. sativum leavesby the antioxidant ascorbic acid.

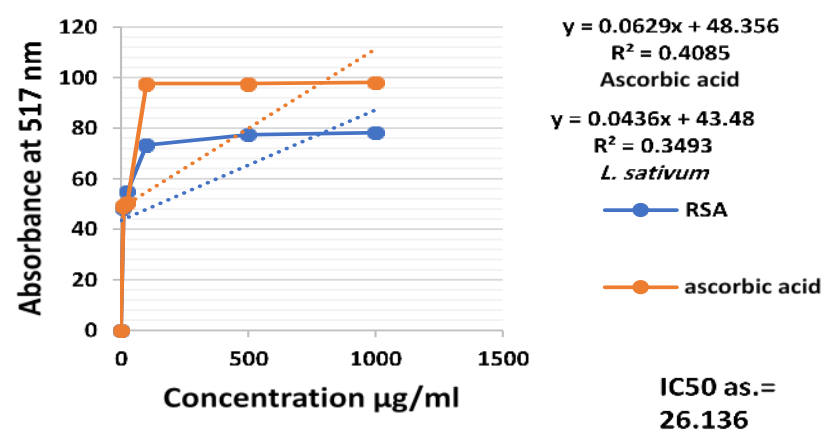

Figure ( 2 ) Calibration curve of percentage inhibition of the free radical DPPH by L.sativum leaves of glycoside and ascorbic acid.

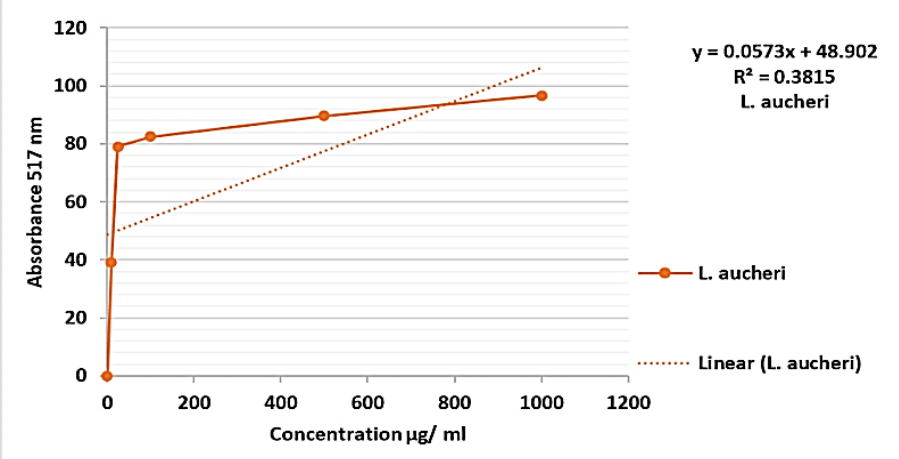

Figure (3) Calibration curve of percentage inhibition of the free radical DPPH by L.aucheri leaves of glycoside.

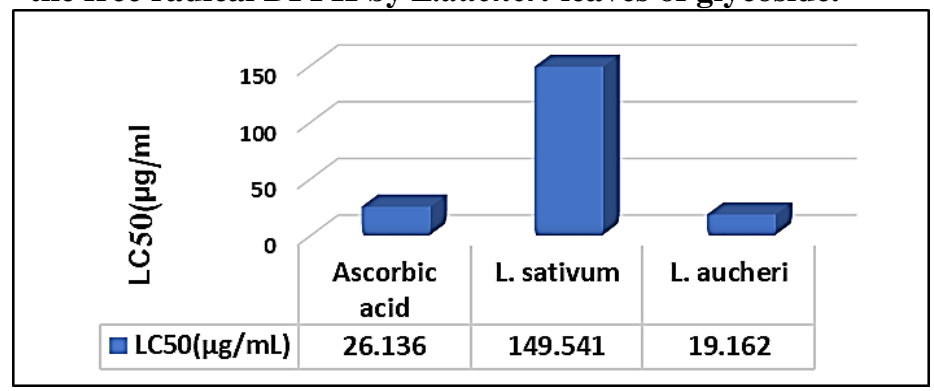

Figure (4): IC50 values of the different glycoside extracts in DPPH scavenging assay.

3- Chemical glycosides composition of $L$. sativum and $L$. aucheri leaves.

The GC-MS chromatogram of L. satvium and

L. aucheri leaves glycosides (Figure 5; Table1). 
The GC analysis indicated that $L$. sativum had high number of glycoside compounds 34 components compared with $L$. aucheri 21 components. The major components of $L$. sativum were found to be: Benzyl nitrile (22.24\%), N,NDimethylamino ethanol(17.53\%),4H-Pyran-4one,2,3-dihydro-3, 5 - dihydroxy-6-methyl- (12.48 $\%)$; 2-Hydroxy-1-(1'-pyrrolidiyl)-1-buten-3-one $(11.08 \%)$, D-Proline (7.33 \%), Butyrolactone $(4.97 \%)$ and 1-(1'-pyrrolidinyl)-2-propanone (4.14),

Benzene,

(isothiocyanatomethyl)(2.05\%),Hexadecanoic acid,2-hydroxy-1-(hydroxymethyl)ethylester (1\%) as well as some other compounds were only present in minor amounts. GC -MS analysis of $L$. aucheri represented 21 compounds, DL-Proline, 5-oxo-,methylester(42.26\%);2-

Furancarboxaldehyde ,5-methyl-(12.64\%);4HPyran-4-one, 2,3-dihydro-3,5-dihydroxy-6methyl-(9.87\%);2-Piperidineme- thanol (2.86\%); Tetrahydropyran 12-tetradecyn-1-ol ether (2.80\%); 2-Hydroxy-1-(1'-pyrrolidiyl)-1-buten-3one (2.55\%); Hexadecanoic acid, 2-hydroxy-1(hydroxymethyl) ethyl ester (2.33\%); 2-Methoxy4-vinylphenol (2.02\%).

Our results agreed with some research, Malar et al. (2018), which recorded $16.32 \%$ of benzyle nitrile, Benzene, (isothiocyanatomethyl) (3.89\%), Hexadecanoic acid, 2-hydroxy-1-(hydroxymethyl) ethyl ester $(1.14 \%)$. As well as Singh and Singh (2017) recorded Hexadecanoic acid, 2-hydroxy-1(hydroxymethyl) ethyl ester compound (7.13\%). Abu-Rumman (2018) recorded $2.93 \%$ benzyle nitrile, Benzene, (isothiocyanatomethyl) (0.3\%) and Hexadecanoic acid, 2-hydroxy-1(hydroxymethyl) ethyl ester (10.3\%).

Our study indicated that present Butyrolactone compound, this compound identifies in some plants of Mints plants, Butyrolactone has been detected in several different foods, such as pepper (capsicum annuиm), yellow bell peppers, orange bell peppers, soybeans, and evergreen blackberries. Butyrolactone is a toxic compound, but it is also used as a pharmacological agent. This study observed that glycerin absents in L. sativum, but it is present in L. aucheri (1.89\%). 4H-Pyran-4-one, 2,3-dihydro-3,5-dihydroxy-6-methyl- and 2Furancarboxaldehyde, 5-methyl- present in both L. sativum and L. aucheri which agreed with (AlSafi, 2018). These compounds determined in some species of Brassicaceae (Gopalakrishnan and Udayakumar, 2014). DL-Proline, 5-oxo-, methyl ester, found in some plants (Gopalakrishnan and Udayakumar, 2014).

Natural compounds are also important where they prevent the oxidative stress damage (Boudouda et al., 2015). Hexadecanoic acid, 2hydroxy-1-(hydroxymethyl) ethyl ester is important as antimicrobial, antiallergic, hemolytic, pesticide and antioxidant (Singh and Singh, 2017; Abu-Rumman, 2018). Furan compounds such as (2-Furanmethanol and Furaneol) reported as antioxidant;2-Furancarboxaldehyde, 5-methyl-, 2,4-Dihydroxy-2,5-dimethyl-3(2H)-furan-3one useful as antimicrobial, anti-inflammatory, automatic nerve activity, antiproliferative antioxidant. Glycerin compound (nature of compound sugar alcohol) determined in L. aucheri was used pesticides, herbicidal and antimicrobial; while 4H-Pyran-4-one, 2,3-dihydro-3,5dihydroxy6-methyl- antimicrobial; 2-Methoxy-4vinylphenol, Phenolic compound, antioxidant; LProline, 5-oxo-, methyl ester.

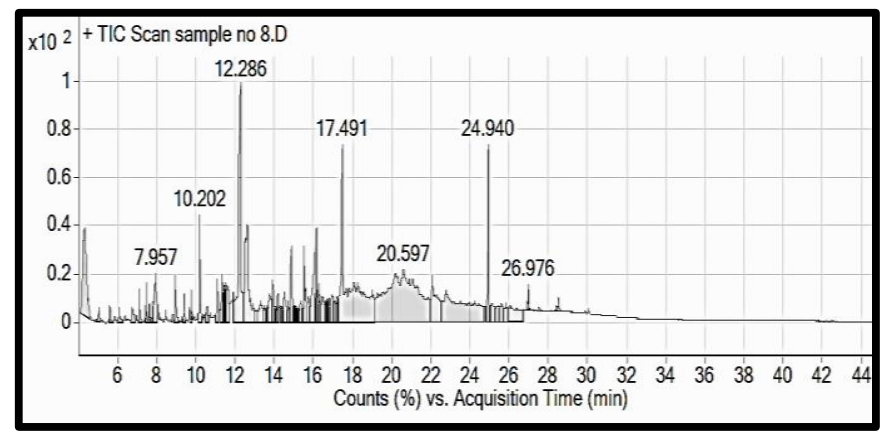

Figure (5) Chromatogram of chemical compounds of Lepidium sativum leaves.

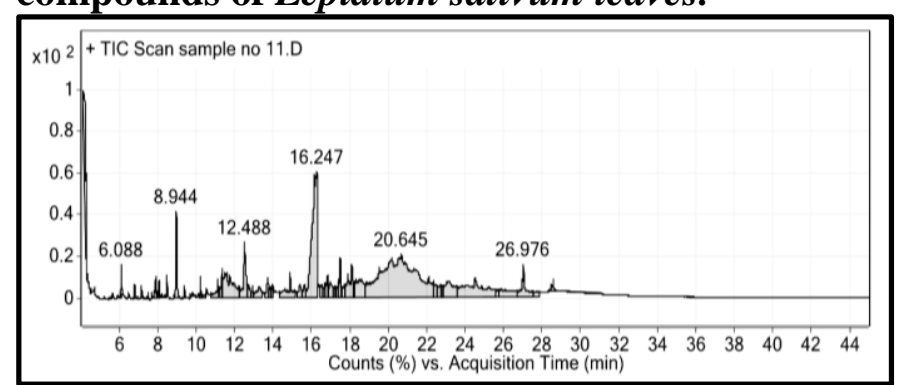

Figure (6) Chromatogram of chemical compounds of Lepidium aucheri leaves. 


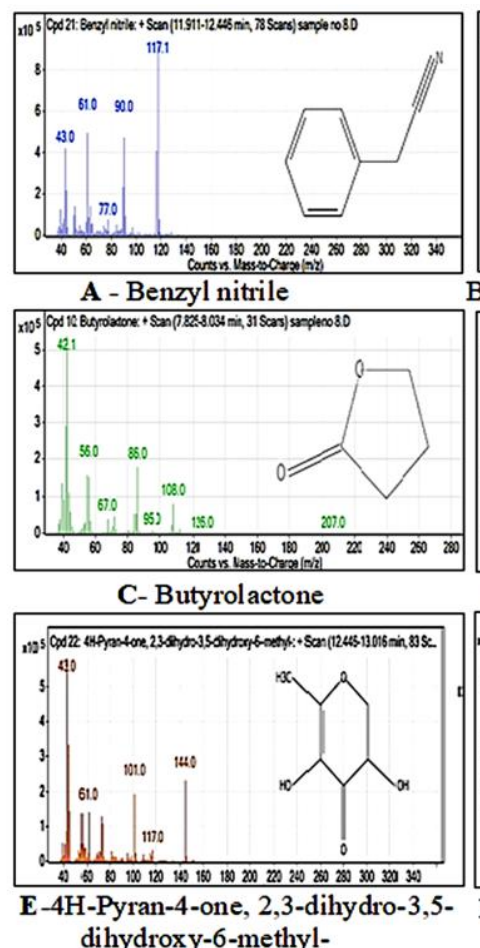

dihydroxy-6-methyl-

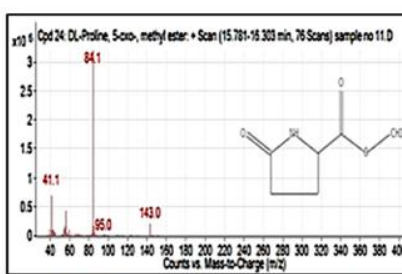

B-DL-Proline, 5-oxo-, methyl est

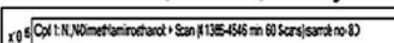

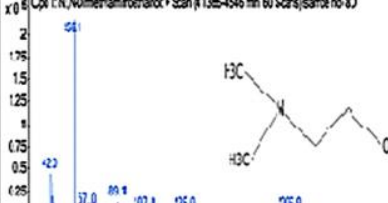

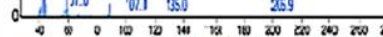
D- N,N-Dimethylaminoethanol

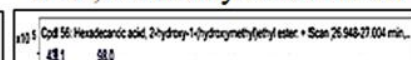

Figure (7) A typical gas chromatogram of the chemical compound of Lepidium aucheri leaves.

Table (1) Chemical constituents of $L$. satvium and $L$. aucheri leaves glycosides by using GC-MS analysis.

\begin{tabular}{|c|c|c|c|c|}
\hline Peak & Chemical constituents & RT & $\begin{array}{c}\text { Area } \\
\% \\
L . \\
\text { aucher } \\
i\end{array}$ & $\begin{array}{c}\text { Area \% } \\
\text { L. } \\
\text { ativum }\end{array}$ \\
\hline 1 & $\begin{array}{l}\text { N,N-Dimethylaminoethanol(Deanol; } \\
\text { Varesal; Bimanol; DMAE; Kalpur P; } \\
\text { Liparon) }\end{array}$ & 4.330 & - & 17.53 \\
\hline 2 & Propanoic acid, 2-oxo-, methyl ester & 5.060 & - & 0.76 \\
\hline 3 & Pyrazine, methyl- & 5.623 & - & 0.88 \\
\hline 4 & 2-Furanmethanol & 6.762 & 1.54 & 1.36 \\
\hline 5 & 4-Cyclopentene-1,3-dione & 7.117 & 1.90 & 1.51 \\
\hline 6 & N-Ethylidene t-butylamine & 7.478 & - & 1.23 \\
\hline 7 & Pyrazine, 2,6-dimethyl- & 7.804 & - & 1.13 \\
\hline 8 & Butyrolactone & 7.957 & 1.63 & 4.97 \\
\hline 9 & 2-Furancarboxaldehyde, 5-methyl- & 8.937 & 12.64 & 1.55 \\
\hline 10 & $\begin{array}{l}\text { 2,4-Dihydroxy-2,5-dimethyl-3(2H)- } \\
\text { furan-3-one }\end{array}$ & 9.396 & 1.62 & 0.94 \\
\hline 11 & $\begin{array}{l}\text { Pyrazine, trimethyl- } \\
\end{array}$ & 9.771 & - & 1.06 \\
\hline 12 & 1-(1'-pyrrolidinyl)-2-propanone & 10.202 & 1.41 & 4.14 \\
\hline 13 & 4H-1,2,4-Triazole, 4-methyl- & 11.105 & - & 1.78 \\
\hline 14 & $\begin{array}{l}\text { 2,5-Piperazinedione, 3-methyl-6-(1- } \\
\text { methylethyl)- }\end{array}$ & 11.348 & - & 1.96 \\
\hline 15 & $\begin{array}{l}\text { 4H-Pyran-4-one, 2,3-dihydro-3,5- } \\
\text { dihydroxy-6-methyl- }\end{array}$ & 11.494 & 9.87 & 12.48 \\
\hline 16 & $\begin{array}{c}\text { Benzyl nitrile (Benzyl cyanide; } \\
\text { Phenylacetonitrile) }\end{array}$ & 12.286 & 1.33 & 22.24 \\
\hline 17 & Pyrazine, 2-ethyl-5-methyl- & 14.524 & - & 1.65 \\
\hline 18 & 2-Methoxy-4-vinylphenol & 14.871 & 2.02 & 3.05 \\
\hline 19 & Benzene, (isothiocyanatomethyl)- & 15.517 & - & 2.05 \\
\hline 20 & Tridecanenitrile & 15.594 & - & 1.11 \\
\hline 21 & 3-Pyridinamine, N,N-dimethyl- & 15.733 & - & 0.69 \\
\hline 22 & Pyrrolidine, 1-(1-cyclohexen-1-yl) & 16.129 & - & 1.74 \\
\hline 23 & Benzeneacetamide & 16.282 & - & 0.79 \\
\hline 24 & $\begin{array}{l}\text { 2-Hydroxy-1-(1'-pyrrolidiyl)-1-buten- } \\
\text { 3-one }\end{array}$ & 17.491 & 2.55 & 11.08 \\
\hline
\end{tabular}

\begin{tabular}{|c|c|c|c|c|}
\hline 25 & $\begin{array}{l}\text { 5,10-Diethoxy-2,3,7,8-tetrahydro- } \\
1 \mathrm{H}, 6 \mathrm{H} \text {-dipyrrolo[1,2-a:1',2'-d]pyrazine }\end{array}$ & 22.070 & - & 1.31 \\
\hline 26 & D-Proline & 24.948 & - & 7.33 \\
\hline 27 & $\begin{array}{l}\text { Hexadecanoic acid, 2-hydroxy-1- } \\
\text { (hydroxymethyl)ethyl ester }\end{array}$ & 26.976 & 2.33 & 1.00 \\
\hline 28 & $\begin{array}{c}\text { 4- (2,5-Dihydro-3- } \\
\text { methoxyphenyl)butylamine }\end{array}$ & 14.524 & - & 1.58 \\
\hline 29 & Cyclohexanone, 2-(2-butynyl)- & \begin{tabular}{|l}
14.871 \\
\end{tabular} & - & 2.05 \\
\hline 30 & Benzene, (isothiocyanatomethyl)- & 15.517 & - & 2.05 \\
\hline 31 & $\begin{array}{c}\text { Pyrrolidine, 1-acetyl- } \\
\text { Azocine, octahydro- } \\
\end{array}$ & 12.766 & - & 0.69 \\
\hline 32 & Pyrrolidine, 1-(1-cyclohexen-1-yl)- & 16.129 & - & 1.74 \\
\hline 33 & Benzeneacetamide & 16.282 & - & 0.79 \\
\hline 35 & $\begin{array}{l}\text { 5,10-Diethoxy-2,3,7,8-tetrahydro- } \\
1 \mathrm{H}, 6 \mathrm{H} \text {-dipyrrolo[1,2-a:1',2'-d]pyrazine }\end{array}$ & 22.070 & - & 1.31 \\
\hline 36 & 2-Piperidinemethanol & 6.088 & 2.98 & - \\
\hline 37 & $\begin{array}{l}\text { Acetic acid, 2-(dimethylamino) ethyl } \\
\text { ester }\end{array}$ & 8.458 & 1.50 & - \\
\hline 38 & $\begin{array}{l}\text { Cyclopentane, 1-methyl-2-(2- } \\
\text { propenyl)-, trans- }\end{array}$ & 11.091 & 1.43 & - \\
\hline 39 & Furaneol & 11.313 & 2.19 & - \\
\hline 40 & Glycerin & 11.703 & 1.89 & - \\
\hline 41 & $\begin{array}{c}\text { Tetrahydropyran 12-tetradecyn-1-ol } \\
\text { ether }\end{array}$ & 13.683 & 2.80 & - \\
\hline 42 & DL-Proline, 5-oxo-, methyl ester & 16.122 & 42.26 & - \\
\hline 43 & Pyrrolidin-2-one, 5-pentyl- & 16.796 & 1.41 & $\begin{array}{l}- \\
-\end{array}$ \\
\hline 44 & $\begin{array}{c}\text { 4-Methyl-2,5- } \\
\text { dimethoxybenzaldehyde }\end{array}$ & 18.054 & 1.84 & - \\
\hline \multirow[t]{2}{*}{45} & $\begin{array}{c}\text { 1-Amino-4,6-dimethyl-2-oxo- } \\
\text { 1,2-dihydropyridine-3- } \\
\text { carbonitrile }\end{array}$ & 24.460 & 2.86 & - \\
\hline & & & 100 & 100 \\
\hline
\end{tabular}

IV.

\section{CONCLUSION}

In the present study, the identified phytocompounds of two species of Lepidium with molecular formula and structure, Thus the GC-MS analysis is the first step towards understanding the nature of active principles in Lepidium species. This study has been good source to produce many modern drugs and drug development (Ravi et al., 2018). The two species of Lepidium have presence of biological active chemicals such as isothiocyanates and some phytochemical components such as benzyle nitrile, furan and glycerin compound, the presence of phytochemicals leaves of $L$. sativum may be responsible for controlling diseases.

Natural products and biological effects of Lepidium species are reported in this study, the phytochemical study of the Leaves of this species has led to the separation and identification and we found the DPPH is good exhibited. The results of this study indicate that glycoside extract of $L$. sativum leaves possess significant antioxidant properties,

\section{REFERENCES}


Abdel Karim, M.; Sufian, A.; Kamal, M.S. and Inas, O. (2017). GC-MS Analysis and antimicrobial activity of fixed oil from Saudi Lepidium sativum (Crusifereae) seed. Int. J. Adv. Res. 5(3): 1662-1670.

Abu-Rumman, A. M. (2018). Gas chromatography-mass spectrometry (GC-MS) analysis of extracted oil from whole garden cress (Rashaad) seeds. American journal of engineering research, 7(4):1-8.

Ahamad, R., Mujeeb, M.; Anwar, F. and Ahmad, A. (2015). Phytochemical analysis and evaluation of antioxidant activity of methanolic extract of Lepidium sativum L. seeds. Der. Pharm. Lett., 7 (7) :427-434.

Ahsan, S.K.; Tarig, M.; Ageel, M.; Alyanya, M.A. and Shah, A.H. (1989). Studies on some herbal drugs used in fracture healing. Int. J. Crude Drug Res., 27: 235-239.

Ait-yahia, O.; Perreau, F.; Bouzroura, S.; Benmalek, Y.; Dob, T. and Belkebir, A. (2018). Chemical composition and biological activities of nbutanol extract of Lepidium sativum L (Brassicaceae) seed. Tropical journal of pharmaceutical research, 17 (5): 891-896.

Al-Harbi, F.K. (2018). Antioxidant effect of Lepidium meyenii (Maca) root on testis and spinal cord tissues of avian influenza virus- infected chicken embryo. International journal of research in pharmaceutical science. Int. J. Res. Pharm. Sci. 10(1): 612-618.

Al-Mayah, A.A. (2001).) Modern Botany. Abadi center for studies and Publishing Sana'a, Yemen: 260 pp.

Al-Musawi, A. H. (1987). Botany. Baghdad University. Iraq.

Alqahtani, F.Y.; Aleanizy,F.S.; Mahmoud, A.Z.; Farshori, N.N.; Alfaraj, R.;Al-sheddi, E.S.; and Alsarra, I.A. (2019). Chemical composition and antimicrobial, antioxidant, and anti- inflammatory activities of Lepidium sativum seed oil. Saudi journal of biological sciences. 26: 1089-1092.

AL-Shehbaz, I. A. (1984). The tribes of Cruciferae (Brassicaceae) in the southeastern United States. J. Arnold Arb. 65, 343--373.
Al-Snafi, A. E. (2019). Chemical constituents and pharmacological effects of Lepidium sativum review. Int. J. Curr. Pharm. Res., 11(6): 1-10.

Al-Snafi, A.E. (2018). Pharmacological and therapeutic importance of Hibiscus sabdariffa-a review. Int J Pharm Res.,10:451-475.

Aydemir, T. and Becerik, S. (2011). Phenolic content and antioxidant activity of different extracts from Ocimum basilicum, Apium graveolens and Lepidium sativum seeds. Journal of food biochemistry. 35(1): 62-79.

Bhasin, P., Bansal, D., Yadav, O.P., Punia, A. (2011). In vitro antioxidant activity and phytochemical analysis of seed extracts of Lepidium sativum a medicinal herb. J. Biosci.Tech. 2:410-415.

Boudouda,H.B.; Zeghib, A.; Karioti, A.; Bilia,A.; Öztürk, M.; Aouni,M.; Kabouche,A. and Kabouch, Z. (2015). Antibacterial, antioxidant, anti-cholinesterase potential and flavonol glycosides of Biscutella raphanifolia (Brassicaceae). Pak. J. Pharm. Sci., 28(1): pp.153-158.

Chatoui, K.; Talbaoui, A.; Aneb, M.; Bakri, Y.; Harhar, H. and Tabyaoui, M. (2016). Phytochemical Screening, Antioxidant and Antibacterial activity of Lepidium sativum seeds from Morocco. J. Mater. Environ. Sci. 7 (8) 2938-2946.

Czapecka, E., Mareczek, A. and Leja, M. (2005). Antioxiadant activity of fresh and dry herbs of some Lamiaceae species. Food Chemistry, 93: 223-226.

Datta, P.K.; Diwakar, B.K.; Viswanatha, S.; Murthy, K.N. and Naidu, K.A. (2011). Safety evaluation studies on Garden cress (Lepidium sativum L.) seeds in Wistar rats. Int. J. App. Res. Nat. Prod., 4: 37-43.

Eddouks, M.; Maghrani, M.; Zeggwagh, N.A. and Michel, J.B. (2005). Study of the hypoglycaemic activity of Lepidium sativum L. aqueous extract in normal and diabetic rats. J. Ethnopharmacol., 97:391395.

Facciola, S. (1990). Cornucopia-A Source book of edible plants; Kampong Publications: Vista, CA, USA.

Fan, Q.L.; Zhu, Y.D.; Huang, W.H.; Qi, Y. and Guo, B.L. (2014). Two new acylated flavanols 
glycosides from seeds of Lepidium sativum. Molecules, 19: 11341-11349.

Gopalakrishnan, K. and Udayakumar, R. (2014). GC-MS Analysis of Phytocompounds of Leaf and Stem of Marsilea quadrifolia (L.). International Journal of Biochemistry Research \& Review, 4(6): 517-526.

Harborne, J.B., (1984). Phytochemical methods. London chapman and Hall ltd.: pp 49-188.

Hatano, T.; Kagawa, H.; Yasuhara, T. and Okuda, T. (1988). Two new flavonoids and other constituents in Licorice Root: Their relative astringency and radical scavenging effects. Chemical and pharmaceutical bulletin. 36: 2090-2097.

Hussein, H.J.; Hameed, I. H. and Hadi, M.Y. (2017). Using Gas chromatography-mass spectrometry (GC-MS) technique for analysis of bioactive compounds of methanolic leaves extract of Lepidium sativum. Research J. Pharm. and Tech. 10(11): 39813989.

Karimi, E.; Jaafar, H. Z., and Ahmad, S. (2011). Phytochemical analysis and antimicrobial activities of methanolic extracts of leaf, stem and root from different varieties of Labisa pumila Benth. Molecules (Basel, Switzerland), 16(6), 4438-4450.

Kassie, F.; Rabot, S.; Uhl, M.; Huber, W.; Qin, H.M. and Helma, C. (2002). Chemoprotective effects of garden cress (Lepidium sativum) and its constituents towards 2-amino-3-methyl-imidazo[4,5-f] quinoline (Iq)-induced genotoxic effects and colonic preneoplastic lesions. Carcinogenesis, 23:1155-1161.

Kbyeh , F. R. (2015). Study of antimicrobial effect for water extracts of Lepidium Aucheri Boiss. and peel actinidia deliciosa on growth some types of bacteria in vitro. European journal of scientific research, 131 (2): pp.170 - 174.

Lee, Y. and Chang, Y.H. (2019). Physicochemical and antioxidant properties of methanol extract from Maca (Lepidium meyenii Walp.) leaves and roots. Food Sci. Technol, Campinas, 39: 278-286.

Maghrani, M.; Zeggwagh, N.A.; Michel, J.B and Eddouks, M. (2005). Antihypertensive effect of
Lepidium sativum L. in spontaneously hypertensive rats. J. Ethnopharmacol 100:193-197.

Malar, J.M.; Vanmathi, J. and Chairman, K. (2018). Phytochemical analysis of Lepidium sativum using UV-VIS and GC-MS. Int. J. Adv. Res. 6(9): 813825.

Merzouki, A.; Ed-derfoufi, F. and Molero, M.J. (2000). Contribution to the knowledge of Rifian traditional medicine. II: Folk medicine in Ksar Lakbir District (NW Morocco). Fitoterapia, 71: 278-307.

Mullen, W.; Marks, S.C. and Crozier, A. (2007). Evaluation of phenolic compounds in commercial fruit juices and fruit drinks. J. Agric. Food Chem. 55: 31483157.

NIST. (2005). Mass spectral search program for the NIST/EPA/NIH Mass Spectral Library. Version $2.0 \mathrm{~d}$.

Oz, O. (2011). Effects of storage on composition of some vegetables of boiled and drying. Master Thesis. Ataturk University, Graduate School of Natural and Applied Science.

Patel, U.; Kulkarni, M.; Undale, V. and Bhosale, A. (2009). Evaluation of diuretic activity of aqueous and methanol extracts of Lepidium sativum garden cress (Cruciferae) in rats. Trop. J. Pharm. Res. 8:215-9.

Ravi, R.; Zulkrnin, N. S. Rozhan,N. N.; Yuso,N.; Rasat,M.; Ahmad,M.I.; Rehman, N.U.; Mehmood, M.H.; Alkharfy, K.M. and Gilani, A.H. (2011). Prokinetic and laxative activities of Lepidium sativum seed extract with species and tissue-selective gut stimulatory actions. J Ethnopharmacol, 134:878-83.

Rodríguez-Huamán, A.; Casimiro-Gonzales, S.; Chávez-Pérez, J. A.; Gonzales-Arimborgo, C.; Cisneros-Fernández, R.; Aguilar-Mendoza, L. A. and Gonzales, G. (2017). Antioxidant and neuroprotector effect of Lepidium meyenii (maca) methanol leaf extract against 6-hydroxy dopamine (6-OHDA)induced toxicity in PC12 cells. Toxicol Mech Methods, 27(4):279-285.

Sandovala, M.; Okuhamaa,N.; Angelesa, F.M.; Melchora, V.; Condezob,L. A.; Mark, J. and Millera J.S. (2002). Antioxidant activity of the cruciferous vegetable Maca (Lepidium meyenii). Food Chemistry, 79: 207-213. 
Sat,I. G.; Yildirim, E.; Turan, M. and Demirbas, M. (2013). Antioxidant and nutritional characteristics of garden cress (Lepidium sativum). Acta Sci. Pol., Hortorum Cultus, 12(4): 173-179.

Selek, S.; Koyuncu, I.; Caglar, H.G.; Bektas, I.; Yilmaz, M.A. and Gonel, A. (2018). The evaluation of antioxidant and anticancer effects of Lepidium sativum subsp spinescens L. methanol extract on cancer cells. Cell Mol. Biol. (Noisy-le-grand), 64:72-80.

Singh, A. S. and Singh, S.K. (2018). Phytoconstituents estimation of Lepidium sativum L. seed extract using GC-MS spectroscopy. World Journal of pharmaceutical research, 7(1): 1360- 1367.

Soengas, P.; Cartea, M.E.; Francisco, M.; Sotelo, T. and Velasco, P. (2012). New insights into the antioxidant activity of Brassica crops. Food Chem. 134: 725-733.

Townsend, C. C. and Guest, E. (1980). Flora of Iraq. Minis. Agricu. Iraq. 4: 2. 886.

Usher, G.A. (1974). Dictionary of plants used by man; Constable and Company Ltd.: London, UK.

Vuong, Q. V.; Hirun, S., Roach, P. D.; Bowyer, M. C.; Phillips, P. A., and Scarlett, C. J. (2013). Effect of extraction conditions on total phenolic compounds and antioxidant activities of Carica papaya leaf aqueous extracts. Journal of Herbal Medicine, 3(3), 104-111.

Wang, S.Y. and Zheng, W. (2001). Effect of plant growth temperature on the antioxidant capacity in strawberries. J. Agric. Food Chem. 49: 4977.

Xiao, J.; Muzashviti, T.S. and Georgiev, M.I. (2014). Advances in the biotechnological glycosylation of valuable flavonoids. Biotechnol. Adv., 32: 11451156. 